\title{
Metaphorical Language in Best-Selling Books: Byrne's The Secret, the Power book as a Case Study
}

\author{
Hanan Ali Amaireh \\ English Department, Faculty of Arts \\ Philadelphia University, Amman, Jordan
}

\begin{abstract}
In this paper, an attempt is made to study the metaphorical language used in one of the best-selling books, The Secret, the Power by Rhonda Byrne (2010). A lot of literature has been made on analyzing metaphors in different genres, yet how metaphorical language is employed in bestselling books gained little attention from discourse analysts, so this study comes to fill this gap in the literature. The purpose of this paper is to focus on this crucial field of written discourse and best-selling books in particular. It will investigate the linguistic techniques which are employed in a way to persuade the audience to change their behavior or ideas and adopt new ones, especially the use of metaphorical expressions and storytelling. Metaphors will be analyzed according to Lakoff \& Johnson's (1980) perspective of metaphorical expressions and the "Speech Act Theory" proposed by Austin (1962) and Searle (1969). The paper concludes that metaphorical language is an integral part and pervasive in Byrne's writing style. She uses metaphorical expressions to deliver her message indirectly to convince the audience to adopt her ideas to call them for action. The analysis shows that storytelling is also employed by the author as a rhetorical device to persuade the audience of her thoughts.
\end{abstract}

Keywords: best-selling books, conceptual metaphors, speech act theory, storytelling, The Secret, the Power

Cite as: Amaireh, H. A. (2020). Metaphorical Language in Best-Selling Books: Byrne's The Secret, the Power book as a Case Study. Arab World English Journal for Translation \& Literary Studies 4 (3) 66-73. DOI: http://dx.doi.org/10.24093/awejtls/vol4no3.5 


\section{Introduction}

One of the main reasons that best-selling books are so popular is the language that the authors use in these works. Authors use style that appeals to the audience to convince them of the content of the message they want to convey to them and persuade them to do something or uphold some ideas.

The Secret, the Power, written by the Australian author Rhonda Byrne, is considered one of the best-selling books. It received international fame, with over 20 million copies sold and is available in 50 languages. The author herself is recognised as one of the world's most influential people and the ones who shape the world according to the Times Magazine, and Forbes "The Celebrity 100" list. https://www.thesecret.tv/about/rhonda-byrnes-biography/

Thus, her work deserves analysis to investigate the linguistic secrets it includes, which help in making her work and her thoughts very famous, compelling, and persuasive. So this study comes to unravel the linguistic wonders this work has offered for the readers that make it one of the bestselling books.

\subsection{Research Questions}

This study is designed to answer the following questions:

What are the linguistic techniques used in best-selling books that make them so accessible and appealing to the audience?

How are metaphorical expressions employed in best-selling books, and for what reasons?

To answer the previous questions, this paper analyses the language that is used in Rhonda Byrne's book The Secret, the Power (2010), and, in particular, the metaphorical language that the author uses to attract the audience's attention to read the work and influence them. This paper analyses metaphorical language that is used to 'do things' to call the audience for action rather than used for decorative purposes. Having read Byrne's book, I have noticed that she frequently uses metaphorical language to call the audience for action.

Since the paper will analyze the metaphorical expressions used in Byrne's book according to the Speech Act Theory by Searle (1969) and Lakoff \& Johnson's conceptual metaphors, it is essential to shed light on these concepts below.

\subsection{Definition of Key Concepts}

\subsubsection{Speech Act Theory}

According to Austin (1962) and Searle (1969), language is used to "do things", and "in saying something we are doing something" (Austin,1962, p.12). This means that language is not only used to refer to the falseness or truth of some statements; it is also used to perform some actions such as: making requests, giving advice, orders, or warnings. This is the core of what is called "Speech Act Theory". For example, "I do (take this woman to be my lawful wedded wife)" when it is uttered in the context of the marriage ceremony. The groom does not only say this statement; 
he undertakes all the obligations and rights of marriage, and this is called "performative sentences", according to Austin's classification of utterances (p.9).

Since this article will analyze metaphors used in Byrne's book (2010), the next section will shed light on conceptual metaphors, according to Lakoff \& Johnson's perception of metaphors (1980).

\subsubsection{Conceptual Metaphors}

Lakoff \& Johnson, in their distinguished book Metaphors We Live By (1980), demonstrated how metaphorical expressions are pervasive in all aspects of daily communication. They are frequently used to the extent that people do not recognize that they are metaphors. They introduced what they have termed "Conceptual Metaphor" or "Metaphorical Concept" (1980, p. 4).

For example, "ARGUMENT IS WAR" is a conceptual metaphor through which many metaphorical expressions can be generated, such as the following metaphorical expressions:

1) Your claims are indefensible.

2) He attacked every weak point in my argument.

3) I demolished his argument.

4) If you use that strategy, he will wipe you out.

5) He shot down all my arguments. (1980, p. 4).

The Uppercase is used following the conventions of Lakoff \& Johnson to refer to the conceptual metaphor. Following their categorization, the metaphorical concept consists of two semantic notions or domains. ARGUMENT is the Target Domain (TD), and WAR is the Source Domain (SD). Certain features of the Source Domain are mapped or transferred into the Target Domain. So the following expressions: indefensible, attacked every weak point, demolished, wipe you out, and shot down are part of the (SD) WAR. Those metaphorical expressions are an integral part of our daily communication.

After defining the key terms, the next section will review previous research that analyses bestselling books.

\section{Literature Review}

This section will shed light on previous research that analyzed best-selling books. Goatly (2008) conducted a critical discourse analysis of one of the best-selling children's books, which is Harry Potter and the Philosopher's Stone. He applied corpus linguistics in quantitative analysis within a framework of Systemic Functional Grammar (SFG) to examine how Critical Corpus Analysis represents the ideology and meanings of a literary piece. He also analyzed the pragmatic concepts of presupposition, inference, and propositional attitude. He investigated how quantitative analysis can disclose ideology in a text. The quantitative analysis revealed that the world generally acts in accord with the prevailing standards of sexist stereotypes. Moreover, plants and animals are represented in a negative way as dangerous, and with no importance. There is too much focus on 
rules and forbidding and the emphasis on self-control. Readers are expected to accept this kind of school system of rivalry, group punishment, and children are expected to obey the rules and take this severe abuse of power. Goatly asserts that using a quantitative analysis is very important if the study examines a large number of texts, which gives clear evidence that supports a particular argument.

Guanio-Uluru (2015) analyzed two best-selling literary works: the Twilight Series (20052008) and the Hunger Games (2008-2010). She found that there are parallels between the structures of these works. She observed that one prominent aspect of the two series is that their young female narrator-focaliser spend too much of their time discussing the binary of predatorprey. For example, the narrative in the Twilight series by Stephenie Meyer drives the Protagonist Isabella Swan from the status of a victim at the beginning of the series to a strong predator at volume four Breaking Dawn (2012) of the same series. Similarly, Katniss Everdeen, the main protagonist of the Hunger Games novel, struggled both sides of the (prey-predator) binary as she takes part in a contest called "Capitol's Hunger Games". Guanio-Uluru observed that the two protagonists spend a long time in negotiations regarding their position compared to the traditional ideals of males. She investigated the performance of gender relative to the theories of masculine and feminine, according to Judith Butler's concept of gender as performance.

Hnatkovska (2018) has analyzed the Gone Girl novel by Gillian Flynn (2012), one of the best-selling novels. She investigated how the author of the characters tries to mislead the readers by the two main protagonists Amy Dunn and Nick Dunn, a husband and his wife. The misleading takes place at the syntactic level. The researcher analyzed sentence structure variety, average sentence length, and syntactic peculiarities of the pronoun I utterances and their frequency to investigate how the author tries to give clues about the reliability of the narrators. She also analyzed the complexity of the sentences and the types of clauses used by the narrators. In addition, Hnatkovska carried a quantitative analysis to investigate gender differences. She found that the two protagonists are liars, the wife was lying by commission; this is when you present something as true that you actually believe to be false. On the other hand, the husband was lying by omission; this means if you know somebody thinking something to be true that you believe to be false, and rather than saying something, you do not attempt to correct their false belief.

She found that $75.4 \%$ of all sentences produced by the female protagonist Amy are $I$ utterances and this contradict previous studies which show that people who are lying use fewer first-person pronoun $I$. The analysis also shows that she used more negative sentences and passive structures than her husband. Her results regarding the average sentence length (ASL) support previous research, which concluded that if the average sentence length is less than 15.75 then most likely that the speaker conveys a deceptive message. This is true in the novel as both of the protagonists were lying. Hnatkovska has also found that there was a high frequency of asyndectic connection in both discourses, which means an absence of the use of conjunctions between the parts of a sentence. This gives the impression that they are communicating deceptive stories as they are in a hurry to tell them, so they did not use conjunctions. 
Another study that analyzed a best-selling novel is Putri \& Budiarsa (2018). They analysed deixis in the Fault in our Stars by John Green (2012). They examined the relationship between language and contexts in language structure itself. They identified the different types of deixis found in the novel: spatial, temporal, and person deixis. The person deixis consists of first, second, and third-person speakers.

Searching the literature, it is found that best-selling books are not approached in terms of investigating the way metaphorical expressions are employed in them. To the best of my knowledge, metaphors are usually investigated in political language, but they are not examined in best-selling books. So the current study comes to fill this gap.

The next section will analyze the metaphorical expressions that are used in Byrne's book (2010) to convince her audience to do certain things according to Austin (1962) and Searle's (1969) notion of Speech Act Theory and Lakoff \& Johnson's (1980) perspective of Conceptual Metaphors.

\section{Analysis of Metaphors in Byrne's The Secret, the Power $\quad .3$}

Byrne frequently uses metaphors in her book The Secret, the Power. They are not used for decorative purposes; they are used to persuade the audience of her ideas and to call them for action. For example, she says, "without love... you'd be like a stone statue" (2010, p.9). She uses the conceptual metaphor "NO LOVE, NO LIFE"; she compares being void of love to a non-living thing, which is a stone statue, which means that our life will be rigid if we do not love people or things around us. Here Byrne calls the audience to love everything they do or have in their life. She also quotes other people's sayings to support her argument. She quotes the famous poet Robert Browning's words "Take away love and our earth is a tomb" (p.9), in which a metaphor is also used by comparing life to a grave if it is void of love.

She also speaks metaphorically about the fact that "As you sow, so shall you reap", she says: "It doesn't matter whether your thoughts and feelings are good or bad, you are giving them out, and they will return to you as automatically and precisely as an echo returns the same words you sent out" (Byrne, 2010, p.9). Byrne uses the conceptual metaphor "THOUGHTS AND FEELINGS ARE AN ECHO"; she compares the results of our actions to an echo that returns precisely what we say. She emphasizes that everything happens is definitely a consequence of our deeds. This is a statement that implies a piece of advice that is expressed through using metaphorical language instead of being directly stated. This is what is called the "illocutionary meaning" (Austin, 1962, p. 98), which goes beyond the literal meaning, or what is called the speaker's meaning or the intended meaning. Another metaphorical image used by Byrne is comparing people to a caged parrot; she notes:

If you parrot negative things and squawk about the things you don't love, you are literally jailing yourself, like a parrot in a cage. Every time you talk about what you don't love, you are adding another bar to the cage and you are locking yourself away from all the good. (Byrne, 2010, p.19) 
If people speak about the undesirable things in their life, they will imprison themselves, and repeatedly talking about them will make things worse and add more barriers and constraints to that cage as Byrne believes. Abstract ideas are compared to physical things we can see to create a more tangible image. She creates a unified image using many lexical words: the verbs "parrot", "squawk", the nouns "parrot", "bar", and "cage" and the sentences "you are literally jailing yourself", and "you are adding another bar". This is what is called an original metaphor by comparing people to a caged parrot. It is noticeable how Byrne also uses parallelism as a rhetorical device to emphasize her points and convince the audience of her ideas and motivate them to adopt her thoughts and act in response and change their behaviors. Parallelism is a rhetorical device which relies on the repetition of the same structural pattern (Wales, 2001, p. 283). The structural patterns "you are literally jailing yourself", "you are adding another bar", and "you are locking yourself away" are used. Parallelism is used to catch the audience's attention to the idea the author wants to convey and highlight. Another metaphor used by Byrne related to the image of birds is quoted below:

People who have great lives talk more about what they love. By doing so, they gain unlimited access to all the good in life, and they are as free as the birds that soar in the sky. To have a great life, break the bars of the cage that is jailing you; give love, talk only about what you love, and love will set you free. (Byrne, 2010, p. 20)

Byrne repeats the metaphorical image of the bird; the conceptual metaphors "PEOPLE ARE PARROTS" and "LOVE IS FREEDOM"; she compares talking about what we love to free birds that fly high in the sky. By speaking about the things we do not like, we are imprisoning ourselves. Love is personified; she compares love to a jail guard, by talking nicely to him; he will send you out of prison. Byrne draws a big picture of antonyms of freedom and imprisonment as a result of talking about the things we love or do not love. She turns abstract ideas into tangible images. She calls the audience for action and tries to convince them to speak about what they love to achieve and what they wish to fulfill.

Byrne uses repetition to hammer home the thoughts and ideas she wants to convince her audience with, she says "the force of love can set you free" (2010, p. 21). She also uses the storytelling technique to emphasise her ideas and convince her audience to apply this valuable rule in their life. She narrates a personal story she knows, she says:

I know of a woman who through love alone broke the bars that caged her. She had been left in poverty and faced with bringing up her children by herself after twenty years of an abusive marriage. Despite the extreme hardship she faced, this woman never allowed resentment, anger, or any ill feeling to take root inside her. She never talked negatively about her ex-husband but instead gave only positive thoughts and words about her dream of a new, perfect, beautiful house, and her dream of traveling to Europe. Even though she had no money to travel, she applied for and got a passport and bought small items she would need on her dream trip to Europe. Well, she did meet 
her perfect and beautiful new husband. And after marrying, they moved to her husband's home in Spain overlooking the ocean, where she now lives in happiness. (Byrne, 2010, p. 21)

Storytelling is mixed with metaphorical language; she repeats the metaphorical image of the bird and the cage. Storytelling is a rhetorical technique that is used to stir the audience's emotions and convince them of the speaker's / author's ideas and viewpoints. Anderson (2008) and Amaireh (2013) have found that females use storytelling in their language in order to stir the audience's emotions and convince them of their ideas and thoughts and ask them to do certain actions. Another interesting and original metaphor used by Byrne is comparing words and thoughts to a rocket ship, she says:

Imagine your thoughts and words as being like a rocket ship, and your feelings as the fuel. A rocket ship is a stationary vehicle that can't do anything without fuel, because the fuel is the power that lifts the rocket ship. It is the same with your thoughts and words. Your thoughts and words are vehicles that can't do anything without your feelings, because your feelings are the power of your thoughts and words!. (Byrne, 2010, p. 28)

Byrne used the metaphorical concept THOUGHTS AND WORDS ARE A ROCKET SHIP. This is what is called "original", "innovative", "imaginative" or a "bizarre" metaphor in which the writer or the speaker coins this metaphor (Newmark, 1988, p. 112), (Lakoff \& Johnson, 1980, p. 139). The author's message and perspectives are conveyed by using this type of metaphorical expression. Additionally, it highlights the idiosyncrasy of the author. Byrne turns abstract ideas like feelings and thoughts into tangible images that can be seen and felt such as the rocket ship, fuel, and vehicles.

\section{Conclusion}

The language that is used in best-selling books is worth to be analyzed to investigate how the authors try to convince their readers and to use a style that appeals for them to reach a big audience. This paper concludes that metaphorical language is highly used in this best-selling book by Byrne (2010), and this is one of the secrets and the power of the success of this book. Byrne has used many metaphors not only to decorate the language she uses but also to convince the audience of her ideas and to call them for action to accept her beliefs and change the older ones. This is in line with the Speech Act Theory propounded by Austin (1962) and Searle (1969).

The author has also used other rhetorical devices such as storytelling to convince the audience of her viewpoints, which is a device that is frequently used by females to persuade the audience of the speakers' or the writers' ideas and to stir their emotions. Repetition, such as the rhetorical device parallelism, was used in Byrne's work in order to emphasise her points and hammer home her ideas to achieve her goals of convincing the audience and changing their attitudes, behaviours or thoughts according to her perspectives of life.

Arab World English Journal for Translation \& Literary Studies 


\section{About the Author:}

Dr. Hanan Ali Amaireh is an Assistant Professor. She has been teaching English Language and Linguistics at the English Department, Faculty of Arts at Philadelphia University, Jordan since 2013. She received her Ph.D. from the University of Aberdeen, Scotland, UK, specializing in Discourse Analysis. Her research interests include: Political discourse analysis, discourse and gender, and discourse and media.

https://orcid.org/0000-0003-1235-9048

\section{References}

Amaireh, H. (2013). A Rhetorical Analysis of the English Speeches of Queen Rania of Jordan. Ph.D. thesis. Aberdeen: Aberdeen University.

Andersen, C. (2008). The Obama Phenomenon: A comparative rhetorical analysis. MA. Thesis. Copenhagen Business School, Denmark.

Austin, J. (1962). How to do things with words. Oxford: Clarendon Press.

Byrne, R. (2010). The Secret, the Power. London: Simon \& Schuster.

Goatly, A. (2008). Corpus linguistics, systemic functional grammar and literary meaning: a critical analysis of Harry Potter and the Philosopher's Stone. Ilha do Desterro: A Journal of English Language, Literatures in English and Cultural Studies, (46), 115-154.

Guanio-Uluru, L. (2015). Female Focalizers and Masculine Ideals: Gender as Performance in Twilight and the Hunger Games. Children's Literature in Education, 47(3), 209-224.

Hnatkovska, O. (2018). The Syntax of Unreliable Narrators' I-Utterances In Gone Girl By G. Flynn. Linguaculture (1), 1-15.

Lakoff, G., \& Johnson, M. (1980). Metaphors we live by. Chicago: University of Chicago Press. Newmark, P. (1988). A Textbook of Translation. London: Prentice-Hall international.

Putri, A., \& Budiarsa, M. (2018). The Analysis of Deixis in the Novel The Fault in Our Stars by John Green. Humanis, 22(3), 697-703.

Searle, J. (1969). Speech Acts. London: Cambridge University Press.

Wales, K. (2001). A Dictionary of Stylistics (2nd ed.). London: Pearson Education limited. Websites:

https://www.thesecret.tv/about/rhonda-byrnes-biography/. Retrieved: June 3, 2019.

Arab World English Journal for Translation \& Literary Studies 